can liberal arts colleges do about the tenure system to reduce its corrosive effects on the campus community and to enhance its strong and positive effects? I offer three proposals.

First, the criteria for tenure should be tied more explicitly to what strengthens the campus community, namely, teaching (wisely and carefully assessed), service (especially to the campus community), and scholarship (broadly conceived) - in that order of importance, or perhaps in a variable order that properly credits the distinctive contributions of different tenure candidates.

Second, let us make the probationary period for tenure-track faculty as humane (dare I say nurturing?) as possible. All of us, by every means, should let new faculty know-in the same way that we let new students know-that we want them to make it, that we would consider their failure to earn a lasting place in our campus community to be in large measure a reflection on ourselves.

Third, if all this sounds too starryeyed, let us recognize the competitive advantage of the liberal arts college in narrow economic terms. "The Achilles heel of the American research university," notes Burton Clark $(1987,265)$, is its "inability to reward excellent undergraduate teaching. ... Year in and year out, major universities send away brilliant young teachers, rather than give them tenure when their scholarship does not measure up" to the narrow standards of the scholarship of discovery. It is our opportunity in the liberal arts colleges to recruit and sustain such people.

In 1991, I left a tenured position at a leading research university to accept one at a small and excellent liberal arts college. As I expected, some of my colleagues were puzzled by this decision. Surprisingly, more were wistfully envious. They, like I, originally had been drawn to the academic vocation by their desire both to teach and shape the lives of young people and to be in every sense a member of a college, not just a department, faculty.

These desires can only be lived out as a member of a close-knit campus community. How foolish, then, would those of us who enjoy such community be to dilute its virtues by slavishly aping the values of the research university.

Note
*This essay was adapted from my
Founders' Convocation address at Rhodes
College in September 1993. I owe much to
the comments and criticisms of several
Rhodes colleagues and gratefully acknowl-
edge my debt to them: Gail Corrington-
Streete (religious studies), Dan Cullen (polit-

ical science), Harmon Dunathan (dean), Mehran Kamrava (international studies), Larry Lacy (philosophy), Cynthia Marshall (English), Jim Vest (French), Valarie Ziegler (religious studies), and, especially, Kenny Morrell (classics).

\section{References}

Boyer, Ernest L. 1990. Scholarship Reconsidered: Priorities of the Professoriate. New York: Carnegie Endowment for the Advancement of Teaching.

Clark, Burton R. 1987. The Academic Life: Small World, Different Worlds. New York: Carnegie Endowment for the Advancement of Teaching.

Oakley, Francis. 1992. A Community of Learning: The American College and the Liberal Arts Tradition. New York: Oxford University Press.

Rosovsky, Henry. 1990. The University: An Owner's Manual. New York: Norton.

Ruscio, Kenneth P. 1987. The Distinctive Scholarship of the Selective Liberal Arts College. Journal of Higher Education 58(1) (March-April):205-22.

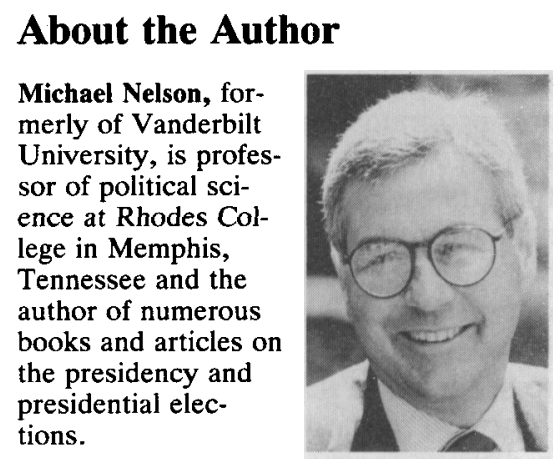

\title{
Introducing a Feminist Pioneer in Judicial Politics: Beverly Blair Cook
}

\author{
Lynn Mather, Dartmouth College
}

\author{
Author's Note: At the 1992 APSA \\ meetings, Gayle Binion and I orga- \\ nized a roundtable tribute to the \\ contributions of Beverly Blair Cook \\ to the field of law and courts. \\ Other participants in the session \\ included Laurence Baum, Sue \\ Davis, Sheldon Goldman, and Bev- \\ erly Cook. I have drawn on the \\ comments from that roundtable to \\ provide an introduction to Cook \\ and her accomplishments.
}

In "Ghosts and Giants in Judicial Politics," Beverly Blair Cook examines the early years of the law and courts subfield and reclaims the lives and histories of its women pioneers. Cook is a pioneer herself and deserves scholarly recognition beyond the confines of the subfield. Currently professor emeritus from the University of WisconsinMilwaukee, Bev Cook began her studies in political science at
Wellesley College, earning her B.A. in 1948, and attending the University of Wisconsin-Madison for her M.A. in 1949. She then taught political science at Iowa State University before temporarily "retiring" to bear four children. She returned to graduate school in 1960 and received her Ph.D. from Claremont University and Graduate School in 1962. Cook taught for four years at California State University, Fuller- 
ton, where she received tenure and promotion to associate professor in 1966. She met political scientist Neil Cotter at an NSF summer seminar at Virginia Polytechnic Institute. They married, joined forces with their eight children, and moved to the University of Wisconsin-Milwaukee for the next twenty-two years.

Her first book, The Judicial Process in California (1967) set out themes echoed in her later work: that the judicial process is an essential part of the political process; that the identity (background, age, race, gender, and class) of judges matters; and that study of courts necessitates consideration of participants other than judges such as lawyers, interest groups, police, and litigants. After this book, Cook published close to 40 more articles and book chapters. Cook has also been a distinguished leader in the profession, serving as vice-president of the Midwest Political Science Association (1982-84), vicepresident of the APSA (1986-87), and on numerous boards, committees, councils, and panels. Although officially retired now, Cook continues her research and writing in judicial politics from her home in Atascadero, California.

Beverly Cook's scholarly work reflects enormous breadth in different substantive areas as well as a wide range of methodological approaches. Among the topics she has addressed are: trial and appellate courts, both at the state and federal level, criminal sentencing, judicial selection, judicial decision making, and women in the judiciary. Some of Cook's articles rest on description and analysis; others explore policy issues; while still others are highly theoretical. She also has demonstrated the usefulness of borrowing from other scholarly literatures-psychology, anthropology, social history, criminal justice, and even biology-in order to improve our understanding of courts and judges.

Cook uses many different methodological approaches in her scholarship, as she has always allowed the nature of the problem to dictate the methodology employed. Included in her research on judges are comparative analyses of individuals, and of courts across different locations and different time periods. She has used case studies, legal doctrine, personal interviews, judicial biographies and memoirs, broad surveys, historical data, and quantitative statistical data. Larry Baum explained how one of Cook's early contributions to the field was the development and refinement of multivariate models for explaining judicial decision making. Baum said that, "although multivariate models are now common in the field, Cook was among those who first showed how this kind of analysis could be done and how much we could learn from it." Cook also has done what too few of us do in our researchreexamine the primary data collected by others in order to generate new ideas for analyzing issues.

One of Cook's significant contributions lies in her research on socialization (both on-the-job and through prior experiences) to explain judicial decision making. In an early Washington University Law Quarterly article (1971), for example, she explored the socialization of federal district court judges; she then studied the on-thejob training of judges in urban trial courts in the Western Political Quarterly (1972); she examined the influences of judges' backgrounds on their sentencing behavior in a 1973 piece. Baum points out that this interest has continued in her work, as seen in a recent study (1991) which provides a "sensitive treatment of Sandra Day O'Connor's life experiences and how those experiences affected her values on the bench."' The O'Connor chapter (1991) also shows Cook's use of constitutional law analysis to reconceptualize the notion of judicial values.

Cook's research on the impact of political and legal culture on judicial behavior reflects a second major theme in her work, and a contribution for which she is widely cited. She showed, for example, that there was a high correlation between criminal sentencing decisions of state and federal judges in the same geographic area-and this despite the very different laws that governed state and federal sentenc- ing at the time (1979). Another look at the influence of culture on sentencing is found in her study of the persistent differences between judges in the western and eastern parts of Wisconsin in their treatment of unpatriotic offenders during four wartime periods (1983). Here she argued that the judges' environmental context was an important determinant of their decision making, and she explores several possible linkage mechanisms. These linkage mechanisms are also tested in what is perhaps Cook's most important work on public opinion and sentencing, her AJPS article (1977) which showed the relationship over time between public opinion on the Vietnam War and the sentences of federal judges in draft cases.

Sheldon Goldman surveyed the many contributions of Beverly Cook on judicial selection, a third area of her research, and noted that she is perhaps best known for her work on the selection of women judges. In the late 1970s, Cook amassed an enormous data base on all women judges-at the state, local, and federal level-and used it in a series of seven articles to explore how and when women were selected for the bench. She advanced and tested ideas about a state's political culture, court size and organizational structure, political party influence, method of judicial selection, and the place of women in the legal profession and in state offices (see, e.g., her 1984a, 1984b, and 1986 articles).

Another fascinating piece on the selection of women judges drew on presidential papers and judicial memoirs to reveal the story of Florence Allen's candidacy to be the first woman appointed to the U.S. Supreme Court (1981a). As Goldman described Cook's work, "Allen [the first woman federal judge] was a candidate for at least 10 of the 12 vacancies on the Supreme Court that occurred during the Roosevelt and Truman administrations. In this article, Bev examined Florence Allen's background and compared it to the famous composite of the typical Supreme Court Justice drawn by John Schmidhauser."' Beverly Cook 
found that Allen fit the picture except for her sex but that she "did not have a large enough constituency to demand the recognition of a Supreme Court seat" (1981a).

While exploring the politics and context governing selection of women judges, Cook also examined the impact of gender on judicial decision making. Both Gayle Binion and Sue Davis emphasized the contributions Cook has made to feminist jurisprudence, feminist social history, and judicial behavior. Davis suggested that Cook's most important contribution has been in the agenda she has set for the study of women judges as decision makers. In articles published in $1980,1981 \mathrm{~b}$, and 1988, she explored whether women judges would make a difference in cases of equality and women's rights; her results, not surprisingly, were mixed. In asking whether women judges decide differently from their male counterparts-either in outcomes or in their methods of reasoning Cook was asking, beginning in 1980 , the questions that scholars are still trying to answer now.

In sum, Cook has improved our understanding of judges and their decisions through her attention to the impact of socialization, to political culture and public opinion, to judicial selection, and to the difference gender makes. She continues to be an active researcher with two very different publications just in the last few months. In the JPO (1993a), Cook proposes a new measure for identifying the "significant" cases of the U.S. Supreme Court, while in Judicature (1993b) she documents and analyzes the fascinating career of Georgia Bullock, the first woman judge in California.

Having contributed so much already to the field of judicial politics, Beverly Blair Cook now provides us with a wonderful addition in the following article. In "Ghosts and Giants in Judicial Politics," she turns her attention from the history of women judges to the history of women political scientists studying judges and the legal process. We thank her for this and for all her contributions to political science.

\section{Selected Publications by Beverly Blair Cook}

1967. The Judicial Process in Califormia. Belmont, CA: Dickenson (Wadsworth) Publishing.

1971. "The Socialization of New Federal Judges: Impact on District Court Business," Washington University Law Quarterly Spring, 253-79.

1972. "Role Lag in Urban Courts," Western Political Quarterly 25:234-48.

1973. "Sentencing Behavior of Federal Judges: Draft cases 1972," Cincinnati Law Review, 42:597-633.

1977. "Public Opinion and Federal Judicial Policy." American Joumal of Political Science 21:567-600.

1979. "Sentencing Problems and Internal
Court Reform,"' in The Study of Criminal Courts, ed. Peter Nardulli. Cambridge, MA: Ballinger Press.

1980. "Women Judges and Public Policy on Sex Integration," in Women in Local Politics, ed. Debra W. Stewart. Metuchen, NJ: The Scarecrow Press.

1981a. "The First Woman Candidate for the Supreme Court," Supreme Court Historical Society Yearbook, 1981, 19-35.

1981b. "The Impact of Women Judges upon Women's Legal Rights: A Prediction from Attitudes and Simulated Behavior" in Women, Power, and Political Systems, ed. M. Rendel. New York: St. Martin's Press.

1983. "Sentencing the Unpatriotic: Federal Trial Judges in Wisconsin during Four Wars," in The Quest for Social Justice, ed. Ralph Aderman. Madison: University of Wisconsin Press.

1984a. "Women Judges: A Preface to their History," Women's Forum, Golden Gate Law Review 14:573-610.

1984b. "Women on the State Bench: Correlates of Access" in Political Women: Current Roles in State and Local Politics, ed. Janet Flammang. Madison: University of Wisconsin Press.

1986. "Women Judges in the Opportunity Structure," in Women, the Courts, and Equality, ed. L. Crites and W. Hepperle. Sage Yearbook in Women Policy Studies.

1988. Women in the Judicial Process (with L. Goldstein, K. O'Connor, and S. Talarico). Washington, DC: APSA.

1991. "Justice Sandra Day O'Connor: Transition to a Republican Court Agenda." In The Burger Court, ed. Charles M. Lamb and Stephen C. Halpern. University of Illinois Press.

1993a. "Measuring the Significance of Supreme Court Decisions." The Journal of Politics 55:1127-39.

1993b. "Moral Authority and Gender Difference: Georgia Bullock and the Los Angeles Women's Court." Judicature 77:14455.

\section{Ghosts and Giants in Judicial Politics}

\section{Beverly B. Cook, Professor Emeritus, University of Wisconsin-Milwaukee}

\author{
A scientist who receives a prize \\ has a conventional modest dis- \\ claimer: I am standing on the \\ shoulders of giants. My response to \\ being honored by this panel is to \\ point to two lines of predecessors, \\ on whose scholarship I have tried \\ to build. One is a line of male giants; \\ the other a line of female ghosts. \\ I begin with the giants (Good- \\ now, Corwin, and Schubert) and \\ proceed with the ghosts-two
}

women (Breckinridge and Paul) who were invisible to the discipline, although giants in their own arenas, and one (Williams) who disappeared. The scarcity of giants and ghosts locates them at the tails of the natural curve; on the two curves are the productive scholars and the radical innovators and at the peak the teachers who interpret the others' writings for students.

\section{The Giants of Judicial Politics}

The identification of a giant depends upon one's own definition of the subfield. ${ }^{1}$ My preference for "judicial politics" over "law and courts," for hands-on data collection over canned computer files, and for statistical analysis over logical exegesis leads me to the first giant in my chain. Frank J. Goodnow (b. 1860) broke sharply from 